\title{
PEMANFAATAN MEDIA ELEKTONIK HANDPHONE SEBAGAI SARANA PENDIDIKAN KESEHATAN REPRODUKSI REMAJA DI SMP 8 KOTA CIREBON
}

\author{
Yeni Fitrianingsih ${ }^{1 *}$, Dewi Vimala ${ }^{1}$ \\ ${ }^{1}$ Program Studi Kebidanan Cirebon Poltekkes Kemenkes Tasikmalaya \\ *email: yfitrianingsih44@gmail.com
}

\begin{abstract}
Health education is an effort to help individuals, groups, and communities to improve their abilities both knowledge, attitudes and skills to achieve optimal healthy living. One way to channel messages is to use multimedia. The dissemination of information about reproductive health is very less compared to the convenience of students in accessing internet information via mobile phones, they can use mobile phones at any time. The negative impact of lack of assistance from parents in using the internet on mobile phones is that they can access sites that lead to inappropriate information. need to convey information about reproductive health education through handphone as an electronic media tool. The target of Cirebon City Senior High School 8 students is 50 people, intervention with counseling is 3 times, given a Micro SD containing knowledge about Adolescent Reproductive Health, evaluation with pre and post test questionnaires, and formed Peer Friend Extension organizations. The majority in the pre test were students who had enough knowledge, namely 27 people (54\%) and the majority at the time of the post test were students who had good knowledge of 32 people (76\%). There is an increase in knowledge about adolescent reproductive health, the formation of Peer Friend Extension organizations Monitoring the activities of peer educators from related parties is very necessary for the sustainability of the program.
\end{abstract}

Keywords : Community Service, Handpone Electronic Media, Adolescent Reproductive Health

\begin{abstract}
ABSTRAK
Pendidikan kesehatan merupakan usaha untuk membantu individu, kelompok, dan masyarakat dalam meningkatkan kemampuan baik pengetahuan, sikap, maupun keterampilan untuk mencapai hidup sehat secara optimal. Salah satu cara untuk menyalurkan pesan adalah dengan menggunakan multimedia. Penyebaran informasi tentang Kesehatan Reproduksi sangat kurang dibanding dengan kemudahan siswa dalam mengakses informasi internet melalui Handphone, mereka bisa setiap saat menggunakan handphone.dampak negatif dari kurangnya pendampingan orang tua dalam menggunakan internet pada handphone diantaranya dapat mengakses situs yang mengarah pada informasi yang kurang tepat. perlu menyampaikan informasi tentang pendidikan kesehatan reproduksi melalui handpone sebagai alat media elektonik. Sasaran siswa siswi SMPN 8 Kota Cirebon sebanyak 50 orang, dilakukan intervensi dengan penyuluhan sebanyak 3 kali pertemuan, diberikan Micro SD berisi pengetahuan tentang Kesehatan Reproduksi Remaja, evaluasi dengan kuesioner pre dan post test, dan dibentuk organisasi Penyuluh Teman Sebaya. Mayoritas pada pre test adalah siswa yang berpengetahuan cukup yaitu 27 orang ( 54\% ) dan mayoritas pada saat post test adalah siswa yang berpengetahuan baik yaitu 32 orang (76\%). Adanya peningkatan pengetahuan tentang kesehatan reproduksi remaja, terbentuknya organisasi Penyuluh Teman Sebaya Monitoring kegiatan penyuluh teman sebaya dari pihak pihak terkait sangat diperlukan untuk keberlangsungan program.
\end{abstract}

Kata Kunci : Pengabdian Masyarakat, Media Elekrtonik Handpone, Kesehatan Reproduksi Remaja 


\section{I . PENDAHULUAN}

Remaja merupakan kelompok yang unik dengan kebutuhan yang khas, yaitu kebutuhan untuk mengenal identitas/jati dirinya. Dalam memenuhi kebutuhannya tersebut, remaja cenderung untuk menerima tantangan atau coba-coba melakukan sesuatu tanpa didahului pertimbangan matang, yang akhirnya dapat mendorong remaja ke arah prilaku yang dapat berisiko menimbulkan berbagai masalah yang akan mempengaruhi kesehatannya (Kemenkes RI, 2010:2) Pendidikan kesehatan merupakan usaha atau kegiatan untuk membantu individu, kelompok, dan masyarakat dalam meningkatkan kemampuan baik pengetahuan, sikap, maupun keterampilan untuk mencapai hidup sehat secara optimal (Kadek, 2014). Menciptakan suasana belajar yang menyenangkan, menarik dan imajinatif pada siswa akan lebih mudah mengerti, mengingat dan memahami materi yang disampaikan. Hal tersebut akan berdampak terhadap penerimaan materi yang lebih cepat sehingga materi yang sudah diterima akan selalu diingat dan disimpan di memori seseorang. Berdasarkan uraian diatas maka penulis mempunyai gagasan untuk memberikan pendidikan kesehatan reproduksi melalui penggunaan multi media Hp sebagai sarana meningkatkan pengetahuan pada remaja di SMPN 8 Kota Cirebon.

\section{METODE}

Pendidikan kesehatan dimulai sejak dini, masa remaja merupakan masa yang sangat penting setelah melewati masa kanak kanak untuk menuju masa dewasa..Untuk mempersiapkan mental dan fisik menghadapi perubahan pertumbuhan dan perkembangan yang pesat remaja memerlukan dukungan dari semua fihak selain keluarga diantaranya petugas kesehatan, guru BK atau fihak terkait lainnya. Salah satu solusi dalam meningkatkan pemahaman remaja tentang kesehatan reproduksi adalah dengan mengupayakan pemberian informasi yang tepat.salah satunya dengan pengabdian masyarakat sebagai aktifitas dosen dalam melaksanakan Tridharma perguruan tinggi. Pengabdian masyarakat berpokus pada peningkatan pengetahuan siswa tentang kesehatan reproduksi Remaja. Sasarannya adalah siswa siswi SMPN 8 Kota Cirebon sebanyak 50 orang, dilakukan intervensi dengan penyuluhan sebanyak 3 kali pertemuan, kemudian diberikan Micro SD berisi pengetahuan tentang Kesehatan Reproduksi Remaja agar mereka bisa memutar video di rumah melalui handpone, evaluasi dilakukan dengan cara memberikan kuesioner sebanyak 35 pertanyaan Benar atau salah, dilakukan pre dan post test, pada akhir kegiatan dibentuk organisasi Penyuluh Teman Sebaya, serta mereka dicoba untuk melakukan penyuluhan pada teman sebayanya.

\section{HASIL DAN PEMBAHASAN}

Pembuatan materi pendidikan kesehatan reproduksi berupa video yang dikemas menarik dengan melibatkan tim dari Dinas Kesehatan Kota Cirebon, Video dimasukan ke dalam micro SD yang dapat dimasukan ke dalam hp siswa, video berisi 3 buah sesi.yaitu tentang alat reproduksi remaja, psikologi remaja, dan akibat pernikahan dini.

Setelah dilakukan penyuluhan sebanyak 3 kali pertemuan, dan diberi micro SD untuk bisa dilihat di handpone, maka dari hasil pre dan post test hasilnya adalah Siswa yang mengalami peningkatan pengetahuan tentang kesehatan reproduksi remaja di SMPN 8 Kota cirebon adalah mayoritas yaitu sebanyak 36 orang $(72 \%$ ) dari jumlah 50 siswa. 


\begin{tabular}{lcccc}
\hline PENGETAHUAN & \multicolumn{2}{c}{ PRE TEST } & \multicolumn{2}{c}{ POST TEST } \\
& $\mathrm{N}$ & $\%$ & $\mathrm{~N}$ & $\%$ \\
\hline BAIK & 19 & 38 & 32 & 76 \\
CUKUP & 27 & 54 & 10 & 24 \\
KURANG & 4 & 8 & - & - \\
JUMLAH & 50 & 100 & 42 & 100 \\
\hline
\end{tabular}

Dari tabel di atas dapat disimpulkan pada pre test mayoritas adalah siswa yang berpengetahuan cukup yaitu 27 orang ( $54 \%$ ) dan mayoritas pada saat post test adalah siswa yang berpengetahuan baik yaitu 32 orang $(76 \%)$.

Salah satu cara untuk menyalurkan pesan,(pengetahuan, keterampilan dan sikap) serta dapat merangsang piki ran, perasaan, perhatian dan kemauan adalah dengan menggunakan multimedia,yaitumedia yang menggabungkan dua unsur atau lebih media yang terdiri dari teks, grafis, gambar, foto, audio, video dan animasi secara terintegrasi. Manfaat multimedia dalam pembelajaran pendidikan kesehatan secara umum adalah dapat menciptakan suasana interaktif pada siswa, meningkatkan kualitas belajar, meningkatkan daya tarik, kemauan, imajinasi siswa pada mata pelajaran yang rumit, dan proses pemahaman serta pendalaman materi menjadi lebih cepat dan efektif (Selvi, 2016).

\section{SIMPULAN}

Pelaksanaan Pengabdian Masyarakat dapat meningkatkan kerjasama yang baik dan bersinergis antara lintas sektoral terkait yaitu Dinas Kesehatan dan Dinas Pendidikan Adanya peningkatan pengetahuan siswa tentang kesehatan reproduksi remaja dalam kegiatan Pengabdian Masyarakat. Penyuluh Teman sebaya sangat tepat dalam memberikan penyuluhan tentang kesehatan reproduksi untuk itu telah terbentuk Penyuluh teman sebaya di SMPN 8 Kota Cirebon

Monitoring kegiatan penyuluh teman sebaya dari pihak pihak terkait sangat diperlukan untuk keberlangsungan program.

\section{DAFTAR PUSTAKA}

Elfi, 2016, Efektifitas Metode Focus Group Discussion (FGD) Dalam Peranan Komunikasi Orang Tua Terhadap Perilaku Seksual Remaja Di SMAN 3 Kota Cirebon

Hasanah, Uswatun.2011. Membangun Kesadaran Remaja Berperilaku Sehat (KTI). Yogyakarta : Fakultas Kedokteran Universitas Gajah Mada Israwati. 2007. Keluarga berencana, kesehatan reproduksi, gender dan pembangunan kependudukan. Jakarta : BKKBN

Kadek, 2014. Hubungan Pengetahuan dengan Sikap Remaja tentang Perilaku Seksual Pranikah Pada siswa kelas X di SMA Negeri 1 Manado.Program Studi Ilmu Keperawatan Fakultas Kedokteran Universitas Sam Ratulangi Manado.

Kusmiran E. 2011. Kesehatan reproduksi remaja dan wanita. Jakarta: Salemba Medika.

Mahfiana,dkk (2009). Remaja dan Kesehatan Reproduksi. Ponorogo : STAIN Ponorogo Press.

Mariani NN. 2014. Hubungan pengetahuan remaja, pendidikan kepala keluarga, struktur keluarga dan pengawasan orang tua dengan perilaku seksual remaja Sekolah Menengah Atas kelas XII di Kota Cirebon. Buletin Media Informasi Poltekkes Kemenkes Tasikmalaya.

Pinem S. 2009. Kesehatan Reproduksi dan Kontrasepsi. Jakarta: Trans Info Media. 
Sadiman Arif, Rahardjo dan Haryono H. 2011. Media pendidikan, pengertian, pengembangan dan pemanfaatannya. Jakarta: PT Raja Grafindo Persada.

Saroso, S. 2007. Upaya pengembangan pendidikan melaui pembelajaran berbasis multimedia. Sarwono SW. 2011. Psikologi remaja. Jakarta: Rajagrafindo Persada.

Selvi, 2016. Media Penyuluhan Kesehatan Reproduksi Berbasis Animasi dan Multimedia pada Remaja di Badan Kependudukan Keluarga Berencana Nasional (BKKBN). universitas PGRI Yogyakarta. 